\title{
KAJIAN PERBANDINGAN TEPUNG KACANG KORO PEDANG (Canavalia ensiformis) DENGAN TEPUNG TAPIOKA DAN KONSENTRASI KUNING TELUR TERHADAP KARAKTERISTIK COOKIES KORO
}

\author{
Tantan Widiantara \\ Dede Zainal Arief \\ Eska Yuniar \\ Program Studi Teknologi Pangan, Fakultas Teknik, Universitas Pasundan, Jl. Dr.Setiabudi No 93, Bandung, 40153,
Indonesia \\ E-mail : tantanwidiantara@unpas.ac.id
}

\begin{abstract}
Abstrak
Tujuan penelitian ini adalah untuk menentukan perbandingan tepung koro dengan tepung tapioka dan konsentrasi kuning telur sehingga diperoleh karakteristik cookies koro yang paling baik. Penelitian pendahuluan dilakukan yaitu menentukan formulasi cookies yang terpilih dari tiga macam formulasi modifikasi. Penelitian utama merupakan penelitian lanjutan dari formulasi terpilih pada penelitian pendahuluan, yang menggunakan rancangan acak kelompok (RAK) dan menggunakan rancangan perlakuan yang terdiri dari 2 faktor, yaitu faktor A (perbandingan tepung koro dengan tepung tapioka) dan faktor B (Konsentrasi Kuning Telur). Hasil dari penelitian utama yaitu didapat produk cookies perbandingan tepung koro dengan tepung tapioka terbaik dengan perbandingan 1:1 dengan konsentrasi kuning telur $12 \%$. Pada penelitian ini, cookies koro untuk analisis kimia mengandung kadar air berkisar 2,5\% - 4,5\%, kadar protein berkisar $16,92 \%$ - 36,60\%, sedangkan untuk cookies yang terpilih memiliki kadar lemak 20,36\%, dan kadar pati $28,53 \%$, serta untuk analisis fisik menunjukkan bahwa nilai uji kekerasan diperoleh sebesar 0,97mm/10detik/100g dan uji warna menunjukkan parameter kecerahan sebesar 81.28, warna kromatik a* sebesar 7.39 dan warna kromatik b* sebesar 28.09. Kesimpulan yang didapat dari penelitian cookies perbandingan tepung koro dengan tepung tapioka berpengaruh terhadap karakteristik warna, tekstur, kadar air dan kadar protein cookies, konsentrasi kuning telur berpengaruh terhadap warna, tekstur dan kadar protein cookies, sedangkan interaksi perbandingan tepung koro dengan tepung tapioka dan konsentrasi kuning telur berpengaruh terhadap warna, tekstur, kadar air dan kadar protein cookies koro.
\end{abstract}

\begin{abstract}
The research is aimed to know the comparison between koro and tapioca flour with egg yolk concentrate to get a characteristic of the best koro cookies. The first research is done to state the formula of the chosen cookies among three modification formulas. The main research is the advanced of the chosen formula in the first research that using random plan group (RPG) and two factors of treatment plan, that is factor A (comparison koro and tapioca flour) and factor B (egg yolk concentrate). The result of the main research is cookies product, comparison of koro and the best tapioca flour with ratio 1:1 with egg yolk concentrate $12 \%$. In this research, koro cookies for chemist analysis contains water degree is about $2,5-4,5 \%$, protein is $16,92-36,60 \%$, while for the chosen cookies contain oil degree $20,36 \%$, and starch degree $28,53 \%$, and for physic analysis show that the value of solid test is amount $0,97 \mathrm{~mm} / 10 \mathrm{detik} / 100 \mathrm{gr}$ and colour test show the brightness parameter is 81,28 , cromatic a is 7,39 and cromatic $b$ is 28,09 . The conclusions of the cookies research is, the comparison of koro and tapioka flour influence to the characteristic of cookies colour, texture, water and protein degree, egg yolk concentrate influence to cookies colour, texture and protein degree. While interaction comparison between koro with tapioca flour and egg yolk concentrate influence to koro cookies colour, texture, water and protein degree.
\end{abstract}

Keywords: koro bean flour, tapioca, egg yolk, cookies

\section{Pendahuluan}

Kacang koro pedang (Canavalia ensiformis) merupakan salah satu tanaman lokal yang dapat ditemukan dengan mudah di Indonesia. Koro pedang kini telah tersebar di seluruh daerah tropis dan telah ternaturalisasi di beberapa daerah, termasuk wilayah Jawa Tengah. Dari kandungan gizi, koro pedang memiliki semua unsur gizi dengan nilai gizi yang cukup tinggi, yaitu karbohidrat $60.1 \%$, protein $30.36 \%$, dan serat $8.3 \%$ (Sudiyono, 2010). Kacang koro selain mempunyai nilai gizi yang cukup tinggi juga mempunyai kelemahan yaitu mengandung senyawa HCN yang bersifat toksik bagi tubuh, jika kadarnya melebihi $10 \mathrm{ppm}$. HCN ini dapat dihilangkan dengan beberapa perlakuan yaitu dengan perendaman pada 
kacang koro, serta pengukusan dan perebusan dengan menggunakan suhu relatif tinggi (Wardiyono, 2008).

Adanya komposisi kimia yang cukup besar yaitu kandungan karbohidrat dan protein pada koro pedang membuka peluang baru untuk memanfaatkan koro pedang sebagai bahan baku produk protein rich flour (PRF) atau tepung kaya protein. Kandungan protein tepung kaya protein koro sebesar $37,61 \%$ sedangkan kandungan protein biji koro pedang sebesar $21.7 \%$ (Subagio dkk., 2002).

Pengolahan tepung kacang koro pedang sebagai bahan baku pembuatan produk pangan dapat dilakukan sebagai upaya diversifikasi pangan di masyarakat. Salah satu alternatif pemanfaatan tepung kacang koro pedang adalah sebagai bahan baku pembuatan cookies.

Cookies adalah kue kering yang rasanya manis dan bentuknya kecil-kecil. Cookies merupakan salah satu jenis biskuit yang dibuat dari adonan lunak, berkadar lemak tinggi, relatif renyah bila dipatahkan dan penampang potongannya bertekstur padat (BSN, 1992). Sebagai makanan yang disukai masyarakat diperlukan peningkatan nilai gizi cookies dan penganekaragaman produk cookies. Bahan-bahan yang digunakan untuk pembuatan cookies adalah bahan baku utama seperti tepung terigu protein rendah dan bahan penunjang lainnya gula, pati (pati jagung, gandum, tapioka, dan sebagainya), kuning telur, bahanbahan pengembang serta shortening dan emulsifier (Matz, 1972).

Dalam pengolahan cookies hal yang harus diperhatikan adalah kerenyahan. Bahan baku yang digunakan dalam pembuatan cookies dapat mempengaruhi kualitas akhir cookies, terutama tepung yang digunakan. Tepung yang biasa digunakan untuk membuat cookies adalah tepung terigu.

Tepung terigu merupakan komoditi impor yang konsumsinya selalu meningkat dari tahun ke tahun. Kenaikan impor gandum tersebut untuk konsumsi terigu atas makanan yang berbasis tepung terigu. Selama ini yang paling sering digunakan dalam berbagai pembuatan kue atau cookies adalah tepung terigu, sedangkan komoditi lokal jarang digunakan (Pertiwi, dkk., 2006). Usaha untuk mengurangi ketergantungan tepung terigu, seharusnya kita mulai mencari bahan baku lokal pengganti tepung terigu yang dapat diolah menjadi produk pangan komersial. Beberapa bahan baku yang telah digunakan sebagai pengganti tepung terigu diantaranya singkong, ubi jalar, tepung beras, sorgum, sagu dan sebagainya. Dalam pembuatan cookies, dapat digunakan tepung kacang koro pedang dan tepung tapioka sebagai pengganti tepung terigu.

Tapioka merupakan salah satu bentuk olahan berbahan baku singkong. Komposisi zat gizi tepung tapioka lebih baik bila dibandingkan dengan tepung jagung, kentang, dan gandum atau terigu. Tepung tapioka yang digunakan berfungsi sebagai pengikat bahan-bahan lain, dan pendistribusian bahan-bahan lain secara merata. Tepung tapioka dapat digunakan sebagai pengganti tepung terigu walaupun tidak mengandung gluten karena dalam pembuatan cookies tidak diperlukan gluten untuk pengembangan adonan. Penambahan tepung kacang koro dapat menambah kandungan protein pada cookies yang dihasilkan, karena tepung kacang koro memiliki kandungan protein yang tinggi.

Selain bahan baku, bahan penunjang seperti konsentrasi telur pun berpengaruh terhadap kerenyahan cookies. Dalam pembuatan cookies sering digunakan pengemulsi guna mendapatkan adonan lebih kompak dan kokoh. Pengemulsi yang umum digunakan adalah telur yang dapat melembutkan tekstur cookies dari daya pengemulsi lesitin yang terdapat dalam kuning telur. Konsentrasi kuning telur berpengaruh terhadap tekstur cookies yang dihasilkan, selain sebagai pengemulsi, kuning telur juga berfungsi untuk menambah warna dan rasa, memberikan zat gizi protein dan lemak esensial serta memiliki sifat dapat mengikat udara sehingga jika digunakan dalam jumlah banyak akan diperoleh cookies yang lebih mengembang. Penggunaan kuning telur tanpa putih telur akan menghasilkan cookies yang lembut (Amaliafitri, 2010).

\section{Metode Penelitian}

Penelitian ini terdiri dari dua tahap, yaitu penelitian pendahuluan dan penelitian utama. Penelitian pendahuluan dilakukan untuk menentukan formulasi cookies yang terpilih dari 3 macam formulasi modifikasi, yang akan digunakan untuk penelitian utama.

Penelitian utama merupakan penelitian lanjutan dari formulasi terpilih dari penelitian pendahuluan. Penelitian utama dilakukan untuk mengetahui perbandingan tepung kacang koro dengan tepung tapioka serta konsentrasi kuning telur yang memiliki karakteristik baik pada cookies sehingga diterima oleh konsumen, yaitu dengan cara menentukan perbandingan tepung koro dengan tepung tapioka $3: 1,2: 1$, dan $1: 1$ dan konsentrasi kuning telur $8 \%, 10 \%$, dan 12\% dengan suhu yang sama yaitu $180 \mathrm{oC}$ dan juga lama pemanggangan yang sama selama 10 menit.

Rancangan percobaan yang dilakukan pada penelitian ini adalah Rancangan Acak Kelompok (RAK) dengan pola faktorial $3 \times 3$ dengan 3 kali ulangan. Adapun variabel yang digunakan adalah perbandingan tepung koro dengan tepung tapioka (A) yang digunakan dan konsentrasi kuning telur (B).

Rancangan respon yang akan dilakukan dalam penelitian utama yang dilakukan meliputi respon organoleptik, respon kimia dan respon fisik. Uji organoleptik akan dilakukan terhadap warna, aroma, dan rasa dari cookies koro, yang diujikan kepada panelis untuk dinilai dari masingmasing perlakuan. Uji organoleptik dilakukan berdasarkan tingkat kesukaan panelis dengan menggunakan metode preference test berdasarkan uji hedonik (Soekarto, 1985). Analisis yang dilakukan pada cookies koro yaitu analisis kadar air 
dengan Metode Gravimetri (AOAC, 1995), karbohidrat (pati) dengan Metode Luff Schoorl (AOAC, 1995), protein dengan Metode Kjedahl (AOAC, 1995), kadar lemak dengan Metode Soxhlet (AOAC, 1995). Analisis yang dilakukan setelah diperoleh perlakuan terbaik dari respon organoleptik dan respon kimia kemudian dilakukan respon fisika secara kuantitatif, yaitu uji kekerasan dengan menggunakan alat penetrometer (Sumarmono, 2012) dan uji warna dengan metode kalorimetri (Bassett, dkk, 1994).

\section{Hasil dan Pembahasan \\ Hasil Penelitian Pendahuluan}

\section{Uji Organoleptik}

Berdasarkan hasil uji mutu hedonik didapatkan hasil bahwa formulasi 3 adalah formulasi terpilih karena memiliki banyak keunggulan bila dibandingkan dengan formulasi 1 dan 2. Hasil respon organoleptik dapat dilihat pada tabel 2 .

Tabel 2. Formulasi Terpilih Cookies Koro

\begin{tabular}{c|c|c|c|c|}
\hline \multirow{2}{*}{ Sampel } & \multicolumn{4}{|c|}{ Atribut } \\
\cline { 2 - 5 } & Warna & Rasa & Aroma & Tekstur \\
\hline 179 & 4.85 & 4.35 & 4.65 & 4.35 \\
\hline 742 & 4.68 & $\mathbf{5 . 7 3}$ & 4.79 & 5.01 \\
\hline $\mathbf{1 3 6}$ & $\mathbf{5 . 1 2}$ & 5.13 & $\mathbf{5 . 0 4}$ & $\mathbf{5 . 2 5}$ \\
\hline & & \multicolumn{4}{c}{}
\end{tabular}

Hasil analisis variansi (ANAVA) menunjukan bahwa formulasi 1, 2 dan 3 tidak berpengaruh nyata terhadap penilaian warna yang dihasilkan, akan tetapi nilai rata-rata dari atribut warna sampel 136 lebih tinggi dibandingkan dengan sampel 179 dan 742, sehingga perbandingan sampel 136 lebih disukai oleh panelis.

Penilaian terhadap rasa pada formulasi 2 lebih disukai panelis dibandingkan dengan formulasi 1 dan 3 . Hal ini karena konsentrasi tepung koro dan tepung tapioka yang setara banyaknya. Tepung koro yang dihasilkan masih terdapat $\mathrm{HCN}$ meskipun dengan konsentrasi kecil yang rasanya pahit. Jadi semakin banyak penambahan tepung koro dapat mempengaruhi rasa pada cookies koro yaitu menghasilkan aftertaste yang pahit. Pada formulasi 2 digunakan tepung koro $20 \%$ dan tepung tapioka $20 \%$. Gula dapat mengurangi rasa pahit. Pada formulasi 2 digunakan gula sebanyak $22 \%$. Selain gula, susu bubuk juga dapat memperbaiki rasa. Penambahan susu bubuk pada formulasi 2 lebih banyak dibanding formulasi 1 dan 3 .

Penilaian terhadap aroma pada formulasi 3 lebih disukai panelis dibandingkan dengan formulasi 1 dan 2 . Aroma pada produk pangan dapat dipengaruhi oleh bahan-bahan yang digunakan dan proses pengolahannya. Aroma yang timbul pada cookies koro pada formulasi 3 ini memiliki aroma khas kacang koro karena penambahan tepung koronya lebih banyak jika dibandingkan dengan formulasi 1 dan 2 . Selain itu, penambahan margarin juga dapat menambah nilai aroma karena pada formulasi 3 penambahan margarinnya lebih banyak yaitu $22 \%$, dibanding dengan formulasi 1 yaitu $11,55 \%$ dan formulasi 2 yaitu $18 \%$.

Penilaian terhadap tekstur pada formulasi 3 lebih disukai panelis dibandingkan dengan formulasi 1 dan 2 . Hal ini karena penambahan banyaknya tepung koro, tepung tapioka maupun kuning telur. Tekstur suatu produk berkaitan dengan kadar air dan kadar protein dimana semakin tinggi kadar protein akan semakin menyerap air. Daya serap air tergantung dari mutu protein dan jumlah kandungan asam amino polar dalam protein tepung. Menurut Windrati (2010), asam amino yang mempunyai nilai terbesar pada tepung kacang koro pedang adalah asam glutamat. Asam glutamat termasuk asam amino yang bermuatan (polar), maka asam amino ini mudah menyerap air sehingga apabila tepung kacang koro pedang digunakan dalam pembuatan cookies akan menghasilkan cookies yang memiliki tekstur padat. Semakin banyak penambahan tepung tapioka maka tekstur cookies semakin ringan dan berongga. Pada penambahan kuning telur, semakin banyak, semakin basah adonan sehingga menghasilkan tekstur cookies yang kurang menarik. Selain itu, penambahan banyaknya margarin juga berpengaruh terhadap tekstur cookies. Sifat plastis pada margarin menyebabkan adonan memiliki daya gabung dengan udara lebih besar. Karena margarin bersifat plastis sehingga adonan yang dihasilkan mudah dibentuk produk akhir yang renyah. Lemak membentuk lapisan tipis yang membungkus dan memisahkan partikel-partikel tersebut sehingga partikel tidak berikatan terlalu kompak yang menyebabkan udara mudah menerobos dan keluar pada proses pemanasan (Estiasih, 2013).

\section{Kadar $\mathrm{HCN}$}

Tabel 3. Hasil analisis kadar HCN pada cookies koro

\begin{tabular}{|c|c|} 
Formulasi & $\begin{array}{c}\text { Kadar HCN } \\
(\mathrm{mg} / \mathrm{kg})\end{array}$ \\
\hline 1 & 0,2 \\
\hline 2 & 0,2 \\
\hline 3 & 0,3 \\
\hline
\end{tabular}

Berdasarkan tabel 3 menunjukkan bahwa kadar HCN pada formulasi 3 lebih tinggi dibandingkan dengan formulasi 1 dan 2 karena penambahan tepung koronya memang lebih banyak pada formulasi 3 dibanding formulasi 1 dan 2 .

Setelah didapatkan formulasi terpilih dari respon organoleptik (formulasi 3) kemudian dilakukan uji kadar air, protein, lemak dan pati. Kadar air pada formulasi 3 sebanyak 4\%, kadar protein sebanyak $5,52 \%$, kadar lemak sebanyak $24,55 \%$ dan kadar pati sebanyak 20,07\%, sehingga dapat disimpulkan bahwa formulasi terpilih pada penelitian pendahuluan adalah formulasi 3, sehingga formulasi tersebut selanjutnya akan digunakan dalam penelitian utama. 


\section{Hasil Penelitian Utama}

1. Uji Organoleptik

a. Warna

Berdasarkan hasil analisis variansi terhadap hasil respon organoleptik warna, dapat diketahui bahwa adanya pengaruh nyata terhadap perbandingan tepung koro dengan tepung tapioka, konsentrasi kuning telur serta interaksi perbandingan tepung koro dengan tepung tapioka dan konsentrasi kuning telur. Hasil Analisis variasi respon organoleptik warna dapat dilihat pada tabel 4 .

Tabel 4. Pengaruh perbandingan tepung koro dengan tepung tapioka dan konsentrasi kuning telur terhadap warna cookies koro

\begin{tabular}{|c|c|c|c|}
\hline \multirow{2}{*}{$\begin{array}{c}\text { Perbandingan } \\
\text { Tepung Koro } \\
\text { dengan } \\
\text { Tapioka (A) }\end{array}$} & \multicolumn{3}{|c|}{$\begin{array}{c}\text { Konsentrasi Kuning } \\
\text { Telur (B) }\end{array}$} \\
\hline & $\begin{array}{c}\text { bl } \\
(8 \%)\end{array}$ & $\begin{array}{c}\text { b2 } \\
(10 \%)\end{array}$ & $\begin{array}{c}\text { b3 } \\
(12 \%)\end{array}$ \\
\hline \multirow[b]{2}{*}{ al (3:1) } & $\mathrm{A}$ & A & A \\
\hline & 2.12 & 2.26 & $b^{2.21}$ \\
\hline \multirow[b]{2}{*}{ a2 (2:1) } & B & $\mathrm{A}$ & B \\
\hline & 2.25 & 2.24 & 2.26 \\
\hline \multirow[b]{2}{*}{ a3 (1:1) } & B & $\mathrm{A}$ & $\mathrm{C}$ \\
\hline & 2.23 & $b^{2.27}$ & 2.34 \\
\hline
\end{tabular}

Keterangan : Setiap huruf yang berbeda menunjukan adanya perbedaan yang nyata pada taraf $5 \%$ uji Duncan (Huruf kecil dibaca horizontal dan huruf besar dibaca secara vertikal).

Tabel 4 menunjukkan bahwa pada interaksi perlakuan a3b3 yaitu perbandingan tepung koro dengan tepung tapioka 1:1 dengan konsentrasi kuning telur $12 \%$ memiliki warna yang paling tinggi dengan nilai rata-rata 2,34, sedangkan interaksi perlakuan a1b1 yaitu perbandingan tepung koro 3:1 dengan konsentrasi kuning telur $8 \%$ menunjukkan hasil penilaian paling rendah dengan nilai rata-rata 2,12 , dimana penambahan terbanyak tepung koro ini kurang disukai oleh panelis. Hal ini disebabkan warna yang dihasilkan oleh cookies berasal dari warna tepung yang digunakan. Timbulnya perbedaan warna ini dikarenakan tepung kacang koro pedang memiliki warna yang terlihat lebih kuning dan lebih gelap. Pigmen kuning yang dimaksud adalah karotenoid. Pigmen karotenoid memiliki sifat fisika kimia yang tidak stabil terhadap suhu, cahaya, dan $\mathrm{pH}$.

Tepung koro kaya akan protein. Menurut Astriani (2013), kandungan protein yang lebih tinggi dapat menyebabkan cookies menjadi lebih coklat. Apabila protein pada tepungtepungan bereaksi dengan gula pereduksi akan menyebabkan terjadinya reaksi browning atau pencoklatan membentuk senyawa mellanoidin. Maka dari itu proporsi tepung koro yang lebih banyak akan menghasilkan warna yang lebih coklat meskipun suhu dan lama pemanggangannya sama. Selain tepung koro, kuning telur pun berfungsi memperbaiki warna pada cookies, semakin banyak penambahan kuning telur maka warna cookies semakin pekat. Menurut Muchtadi (2010), kuning telur memiliki pigmen kuning dari xantofil, lutein, beta karoten dan kriptoxantin.

b. Rasa

Menurut Winarno (1997), rasa dipengaruhi oleh beberapa faktor, seperti senyawa kimia, suhu, konsentrasi komponen-komponen bahan penyusun cookies dan interaksi komponen rasa yang lain. Rasa cookies berasal dari bahan pembentuk adonan yaitu tepung koro, kuning telur, dan margarin. Menurut Matz dan Matz (1978) dalam Soliha (2008), gula sebagai bahan pemanis dan garam sebagai bahan membangkitkan rasa pada bahan lainnya, sehingga kedua bahan tersebut dapat meningkatkan kelezatan cookies. Cookies koro memiliki rasa yang khas koro yaitu sedikit pahit dan getir, hal tersebut dikarenakan masih adanya asam sianida yang terkandung meskipun dalam konsentrasi yang kecil. Karena pada saat pembuatan cookies koro proporsi gula dan garamnya sedikit dari setiap perlakuan maka hampir semua panelis tidak menyukai rasa cookies koro karena masih ada rasa pahitnya, sehingga rasa dari setiap perlakuan tidak berbeda nyata.

\section{c. Aroma}

Aroma pada cookies dipengaruhi oleh beberapa bahan yang digunakan, antara lain lemak (margarin), susu, kuning telur dan tepung. Aroma cookies tercium terutama saat cookies dipanggang (Setser, 1995 dalam Millah, 2013).

Aroma yang keluar dari cookies diduga disebabkan adanya reaksi lemak yang ada pada formulasi cookies saat pemanggangan. Gula dan lemak mengalami perubahan konsistensi yaitu meleleh. Selama pemanggangan, pati akan mengalami gelatinisasi, gas CO2 dan komponen aroma dibebaskan (Sugiyono, 2011 dalam Azizah, 2013). Karena pada saat uji organoleptik cookies koro disajikan saat sudah dingin, maka aroma dari cookies tidak terlalu signifikan perbedaanya. Hal ini dipengaruhi karena senyawa volatil yang mudah menguap sehingga aroma dari setiap perlakuan tidak berbeda nyata.

\section{c. Tekstur}

Berdasarkan hasil analisis variansi terhadap hasil respon organoleptik warna, dapat diketahui bahwa adanya pengaruh nyata terhadap perbandingan tepung koro dengan tepung tapioka, konsentrasi kuning telur serta interaksi perbandingan tepung koro dengan tepung tapioka dan konsentrasi kuning telur. Hasil Analisis variasi respon organoleptik tekstur dapat dilihat pada tabel 5 . 
Tabel 5. Pengaruh perbandingan tepung koro dengan tepung tapioka dan konsentrasi kuning telur terhadap tekstur cookies koro

\begin{tabular}{|c|c|c|c|}
\hline \multirow{2}{*}{$\begin{array}{c}\text { Perbandingan } \\
\text { Tepung Koro } \\
\text { dengan } \\
\text { Tapioka (A) }\end{array}$} & \multicolumn{3}{|c|}{$\begin{array}{c}\text { Konsentrasi Kuning } \\
\text { Telur (B) }\end{array}$} \\
\hline & $\begin{array}{c}\text { bl } \\
(8 \%)\end{array}$ & $\begin{array}{c}\text { b2 } \\
(10 \%)\end{array}$ & $\begin{array}{c}\text { b3 } \\
(12 \%)\end{array}$ \\
\hline \multirow{3}{*}{ al (3:1) } & A & B & $\mathrm{A}$ \\
\hline & 2.12 & 2.31 & 2.25 \\
\hline & a & $\mathrm{c}$ & $\mathrm{b}$ \\
\hline \multirow{3}{*}{ a2 (2:1) } & B & $\mathrm{C}$ & B \\
\hline & 2.30 & 2.35 & 2.29 \\
\hline & $\mathrm{a}$ & $\mathrm{b}$ & a \\
\hline \multirow{3}{*}{ a3 (1:1) } & B & $\mathrm{A}$ & $\mathrm{C}$ \\
\hline & 2.28 & 2.25 & 2.3 \\
\hline & b & a & \\
\hline
\end{tabular}

Keterangan : Setiap huruf yang berbeda menunjukan adanya perbedaan yang nyata pada taraf $5 \%$ uji Duncan (Huruf kecil dibaca horizontal dan huruf besar dibaca secara vertikal).

Pada Tabel 5 dapat dilihat pada interaksi perlakuan a2b2 yaitu perbandingan tepung koro dengan tepung tapioka 2:1 dengan konsentrasi kuning telur $10 \%$ memiliki tekstur yang paling disukai panelis dengan nilai rata-rata 2,35, sedangkan interaksi perlakuan alb1 yaitu perbandingan tepung koro 3:1 dengan konsentrasi kuning telur $8 \%$ menunjukkan hasil penilaian paling rendah dengan nilai rata-rata 2,12 , dimana penambahan terbanyak tepung koro ini kurang disukai oleh panelis.

Tepung koro tinggi akan protein dan tepung tapioka tinggi akan amilopektin. Menurut Windrati (2010), asam amino yang mempunyai nilai terbesar pada tepung kacang koro pedang adalah asam glutamat. Asam glutamat termasuk asam amino yang bermuatan (polar), maka asam amino ini mudah menyerap air sehingga apabila tepung kacang koro pedang digunakan dalam pembuatan cookies akan menghasilkan cookies yang memiliki tekstur padat. Tingkat pengembangan dan tekstur suatu bahan pangan salah satunya dipengaruhi oleh rasio amilosa dan amilopektin. Tepung tapioka memiliki amilopektin yang lebih tinggi dari amilosa. Dimana jika mengandung kadar amilopektin yang lebih tinggi produk yang dihasilkan cenderung akan lebih rapuh, sedangkan jika mengandung amilosa yang tinggi produk yang dihasilkan teksturnya akan lebih kokoh. Menurut Moorthy (2004), kadar amilosa tepung tapioka berada pada kisaran $20-27 \%$ sedangkan amilopektinnya sebesar $83 \%$. Selain itu, kuning telur juga berpengaruh terhadap tekstur cookies. Kuning telur berfungsi untuk melembutkan cookies apabila proporsinya pas, jika terlalu banyak, cookies akan lebih mengembang dan kurang renyah, jika terlalu sedikit cookies akan mudah hancur karena kuning telur berfungsi juga sebagai pengikat dan pengemulsi (Farida, dkk, 2008).

\section{Kadar Air}

Kadar air merupakan karakteristik kimia yang sangat berpengaruh pada bahan pangan karena dapat mempengaruhi penampakan, tekstur dan citarasa makanan. Kadar air dalam suatu bahan pangan ikut menentukan kesegaran dan daya awet bahan pangan tersebut. Kadar air juga dapat mempengaruhi sifat-sifat fisik seperti kekerasan.

Hasil perhitungan analisis variansi kadar air menunjukan bahwa faktor perbandingan tepung koro dengan tepung tapioka dan interaksi antara perbandingan tepung koro dengan tepung tapioka dan konsentrasi kuning telur berpengaruh nyata terhadap respon kadar air cookies. Sedangkan pada faktor konsentrasi kuning telur tidak berpengaruh nyata. Hasil Analisis variasi respon kimia analisis kadar air dapat dilihat pada tabel 6

Tabel 6. Pengaruh perbandingan tepung koro dengan tepung tapioka dan konsentrasi kuning telur terhadap kadar air cookies koro.

\begin{tabular}{|c|c|c|c|}
\hline \multirow{2}{*}{$\begin{array}{c}\text { Perbandingan } \\
\text { Tepung Koro } \\
\text { dengan } \\
\text { Tapioka (A) }\end{array}$} & \multicolumn{3}{|c|}{$\begin{array}{c}\text { Konsentrasi Kuning } \\
\text { Telur (B) }\end{array}$} \\
\hline & $\begin{array}{c}\text { bl } \\
(8 \%)\end{array}$ & $\begin{array}{c}\text { b2 } \\
(10 \%)\end{array}$ & $\begin{array}{c}\text { b3 } \\
(12 \%)\end{array}$ \\
\hline al (3:1) & $4^{\text {B }}$ & ${ }^{4.5^{\text {B }}}$ & $\begin{array}{l}\text { B } \\
3.83 \\
a^{-}\end{array}$ \\
\hline a2 (2:1) & $\begin{array}{r}\mathrm{A} \\
3.17 \\
\mathrm{a}^{-}\end{array}$ & $\begin{array}{l}\mathrm{a}^{\mathrm{A}} \\
2.83^{-1}\end{array}$ & $\begin{array}{l}{ }^{\text {B }} \\
b^{4.33} \\
b\end{array}$ \\
\hline a3 (1:1) & $a{ }^{\text {A }}$ & $\begin{array}{l} \\
2.67^{A} \\
a^{2}\end{array}$ & $a 3^{\text {A }}$ \\
\hline
\end{tabular}

Keterangan : Setiap huruf yang berbeda menunjukan adanya perbedaan yang nyata pada taraf 5\% uji Duncan (Huruf kecil dibaca horizontal dan huruf besar dibaca secara vertikal).

Pada Tabel 6 dapat dilihat pada interaksi perlakuan a3b1 yaitu perbandingan tepung koro dengan tepung tapioka 1:1 dengan konsentrasi kuning telur $8 \%$ memiliki kadar air yang paling rendah dengan nilai ratarata $2,5 \%$, sedangkan interaksi perlakuan a1b2 yaitu perbandingan tepung koro 3:1 dengan konsentrasi kuning telur $10 \%$ menunjukkan hasil penilaian paling tinggi dengan rata-rata 4,5. Peningkatan kadar air diduga ada hubungannya dengan tingginya kadar serat didalam tepung koro yaitu sebesar $2,23 \%$, dimana serat mempunyai sifat mengikat air dengan ikatan yang cukup kuat sehingga semakin banyak proporsi tepung koro yang ditambahkan maka semakin tinggi kadar air. Hal ini didukung pernyataan Hood (1980), bahwa serat dalam suatu bahan dapat mengikat air dan walaupun 
dilakukan pemanasan, air yang diuapkan relatif kecil dan kandungan air yang tertinggal dalam bahan masih ada.

Selain itu, penambahan kuning telur juga dapat meningkatkan kadar air karena kuning telur mengandung protein yang dapat mengikat air. Pada saat pengeringan air yang terikat oleh protein tersebut menjadi sulit diuapkan dan menyebabkan cookies yang dihasilkan mempunyai kadar air yang semakin tinggi dengan semakin banyaknnya penambahan kuning telur.

Kandungan air yang terlalu tinggi pada cookies akan menyebabkan cookies kurang renyah, sedangkan cookies dengan kandungan air rendah menghasilkan cookies yang kering dan remah (mudah hancur).

\section{Kadar Protein}

Berdasarkan hasil analisis variansi terhadap hasil respon kimia analisis protein, dapat diketahui bahwa adanya pengaruh nyata terhadap perbandingan tepung koro dengan tepung tapioka, konsentrasi kuning telur serta interaksi perbandingan tepung koro dengan tepung tapioka dan konsentrasi kuning telur. Hasil Analisis variasi respon kimia analisis kadar protein dapat dilihat pada tabel 7 .

Tabel 7. Pengaruh perbandingan tepung koro dengan tepung tapioka dan konsentrasi kuning telur terhadap kadar protein cookies koro.

Keterangan : Setiap huruf yang berbeda menunjukan adanya perbedaan yang nyata pada taraf $5 \%$ uji Duncan (Huruf kecil dibaca horizontal dan huruf besar dibaca secara vertikal).

Berdasarkan tabel 7 dapat dilihat pada interaksi perlakuan a1b3 yaitu perbandingan tepung koro dengan tepung tapioka 3:1 dengan konsentrasi kuning telur $12 \%$ memiliki kadar protein yang paling tinggi dengan nilai rata-rata $36,60 \%$, sedangkan interaksi perlakuan a3b1 yaitu perbandingan tepung koro 1:1 dengan konsentrasi kuning telur $8 \%$ menunjukkan hasil penilaian paling rendah dengan nilai rata-rata 16,92 . Hal ini dapat disebabkan perbedaan perbandingan tepung koro dengan tepung tapioka dan proporsi kuning telur yang bervariasi yang digunakan pada cookies. Serta banyaknya susu skim yang ditambahkan. Semakin banyak proporsi tepung koro, kuning telur dan susu skim semakin tinggi kadar proteinnya.

Protein yang terkandung didalam cookies dipengaruji oleh komposisi bahan penyusun. Dalam pembuatan cookies bahan penyusunnya meliputi tepung, susu skim, kuning telur, gula halus, vanili, margarin, garam dan baking powder. Dari semua bahan penyusunnya, ada beberapa bahan yang kaya akan protein diantaranya adalah tepung, susu skim, dan kuning telur. Menurut Mahmud (2009), kuning telur mengandung protein sebanyak $16 \%$, susu skim mengandung protein sebanyak 26,15\% (Smith, 1972), sedangkan kandungan protein pada tepung yang digunakan yaitu tepung koro 37,61 \% (Subagio, dkk, 2002) dan tepung tapioka 1,1 \% (Tri dan Agusto, 1990).

Berdasarkan hasil analisis kimia dan uji organoleptik terhadap produk cookies koro menggunakan perhitungan uji ranking, perlakuan yang terbaik adalah kode sampel a3b3 yang kemudian dilakukan analisis kadar lemak, pati, kekerasan (penetrometri) dan warna (colorimetri).

\section{Kadar Lemak}

Hasil analisis kadar lemak pada cookies koro dengan perlakuan terpilih a3b3, perbandingan tepung koro dengan tepung tapioka (1:1) dan konsentrasi kuning telur sebanyak $12 \%$ adalah sebesar $20,36 \%$. Hal ini memenuhi SNI 01-2973-1992 dengan kadar lemak minimal cookies (kue kering) yaitu 9,5\%. Lemak didalam makanan memegang peranan penting ialah lemak netral (glycerin). Lemak memiliki efek shortening pada makanan yang dipanggang seperti biskuit, kue kering dan roti sehingga menjadi lezat dan renyah.

Lemak akan memecah struktur kemudian melapisi pati dan gluten, sehingga menghasilkan kue kering yang renyah (Haryanto, 2009).

Menurut Matz (1978), dalam Haryanto (2009), menyatakan bahwa lemak dapat memperbaiki struktur fisik seperti pengembangan, kelembutan, tekstur dan aroma. Tingginya kadar lemak disebabkan karena bahan yang digunakan dalam pembuatan cookies yang cukup tinggi seperti margarin ataupun kuning telur.

Menurut Hui (1996), margarin terdiri $80-81 \%$ total lemak. Hal ini didukung juga pendapat De Man (1999), margarin mengandung sejumlah besar lipid dan sebagian dari lipid itu terdapat dalam bentuk terikat sebagai lipoprotein.

\section{Kadar Pati}

Hasil analisis kadar pati pada cookies koro dengan perlakuan terpilih a3b3, perbandingan tepung koro dengan tepung tapioka (1:1) dan konsentrasi kuning telur sebanyak $12 \%$ adalah sebesar $28,53 \%$. Sedangkan hasil analisis kadar protein perlakuan terpilih adalah sebesar 24,04\%. Semakin rendah kandungan protein pada cookies maka kandungan pati semakin tinggi. Pati merupakan homopolimer glukosa dengan ikatan glikosidik. Sifat pati tergantung dari panjang rantai C-nya serta rantai molekul (bercabang atau lurus). Monomer dari pati adalah glukosa yang berikatan bersama dan membentuk karbohidrat kompleks. Pati merupakan polimer glukosa, oleh karena itu kandungan ada keterkaitan antara kandungan protein pada tepung kacang koro pedang dengan kadar pati pada cookies yang dihasilkan.

\section{Kekerasan (Penetrometri)}

Uji kekerasan dengan menggunakan penetrometer, cookies perbandingan tepung koro dengan tepung tapioka $(1: 1)$ dan konsentrasi kuning telur sebanyak $12 \%$ dilakukan sebanyak 10 kali 
ulangan dengan sepuluh titik yang diuji dalam 1 cookies, diperoleh nilai sebesar $0,97 \mathrm{~mm} /$ detik/100 g. Semakin kecil nilai yang didapatkan maka tingkat kekerasan semakin besar, sedangkan jika semakin besar nilai yang didapatkan maka tingkat kekerasannya semakin kecil. Nilai kekerasan cookies menunjukkan kedalaman jarum yang ditusukkan kedalam cookies. Semakin dalam tusukan atau semakin besar nilai kekerasan cookies, maka cookies tersebut semakin rapuh.

Tesktur suatu produk berkaitan dengan kadar air dan kadar protein dimana semakin tinggi kadar protein akan semakin menyerap air. Menurut Sultan dalam Makmoer (2006), daya serap air tergantung dari mutu protein dan jumlah kandungan asam amino polar dalam protein tepung. Kadar protein tinggi yang terkandung dalam tepung koro akan meningkatkan daya serap air sehingga tekstur cookies yang dihasilkan akan kokoh. Pada saat pemanggangan, terjadi proses kenaikan suhu yang mengakibatkan terbentuknya uap air dan terbentuknya gas $\mathrm{CO} 2$. Jika lama pemanggangan ideal maka panas akan berpenetrasi dengan cepat pada bagian bawah dan atas cookies sehingga menyebabkan hilangnya gas pengembang dan air pada bagian tersebut. Tapi bila lama pemanggangan terlalu lama, memungkinkan penetrasi panas pada bagian bawah dan atas cookies yang justru dapat membuat tekstur cookies menjadi lebih keras.

\section{Uji Warna (Colorimetri)}

Pada analisis colorimeter notasi $\mathrm{L}^{*}$ menyatakan parameter kecerahan (Lightness) antara 0-100 yaitu hitamputih. Notasi $a^{*}$ (positif) menyatakan warna kromatik campuran merah-hijau dengan nilai 0 sampai +100 untuk warna merah dan nilai a (negatif) dari 0 sampai -80 untuk warna hijau. Notasi $b^{*}$ (positif) menyatakan warna kromatik campuran biru-kuning dengan nilai 0 sampai +70 untuk warna kuning dan nilai b* (negatif) dari 0 sampai -70 untuk warna biru.

Intensitas warna menggunakan colorimeter pada cookies dengan perlakuan terbaik perbandingan tepung koro dengan tepung tapioka (1:1) dan konsentrasi kuning telur sebanyak $12 \%$ menunjukkan bahwa parameter kecerahan (Lightness) sebesar 81.28 artinya warna mendekati putih (terang), warna kromatik $\mathrm{a}^{*}$ sebesar 7.39 artinya terdapat sedikit warna merah dan warna kromatik b* sebesar 28.09 artinya warna ke kuning-kuningan.

Berdasarkan hasil penelitian, dapat diambil kesimpulan sebagai berikut :

1. Penelitian pendahuluan menunjukkan bahwa formulasi tiga (3) merupakan formulasi terpilih berdasarkan respon organoleptik.

2. Perbandingan tepung koro dengan tepung tapioka berpengaruh secara mandiri terhadap warna, tekstur, kadar air dan protein cookies koro, sedangkan konsentrasi kuning telur berpengaruh terhadap warna, tekstur dan kadar proteinnya saja.
3. Interaksi perbandingan tepung koro dengan tepung tapioka dan konsentrasi kuning telur berpengaruh terhadap warna, tekstur, kadar air dan protein cookies koro.

\section{Daftar Pustaka}

1. AOAC, 1995. Official Methods of Analysis of The Association of Analytical Chemists, Washington D.C.

2. Amaliafitri, A. 2010. Sukses Olah Sponge Cake Cantik. www.okefood.com/read/2010/02/10/ 304/302270/large. diaskes pada tanggal 31 Maret 2016.

3. Astriani. D., (2013), Gula Reduksi. http://dianastriani.Blogspot.com/p/ap a-itugulareduksi._1139.html,Diakses 30 Agustus 2016.

4. Azizah, N.A. 2013. Kajian Perbandingan Tepung Mocaf (Modified Cassava Flour) Yang Disubstitusi Tepunh Kacang Koro Pedang Dan Lama Pemanggangan Dalam Pembuatan Cookies. Skripsi. Jurusan Teknologi Pangan, Fakultas Teknik, Universitas Pasundan, Bandung.

5. Bassett, J., Denney, R.C., Jeffery, G.H., dan Mendham, J. 1994. Kimia Analisis Kuantitatif Anorganik. Kedokteran EGC, Jakarta.

6. BSN. 01-2973-1992. Standar Biskuit. Dewan Standarisasi Nasional. Jakarta.

7. deMan. 1999. Principle of Food Chemistry. Connecticut: The Avi Publishing Co., Inc., Westport Estiasih, T. (2013). Karakteristik Cookies Umbi Inferior Uwi Putih (Kajian Proporsi Tepung Uwi : Pati Jagung dan Penambahan Margarin), Universitas Brawijaya.

8. Farida, Anny. 2008. Patiseri. Jakarta : Direktorat Pembinaan Sekolah Menengah Kejuruan. http://www.bogasari.com/zonakonsu $\mathrm{men} /$ bacaresepbogasari.aspx $\mathrm{t}=$ chocolatechipcookies.

9. Gasperz, Vincent. (1995). Teknik Analisis Dalam Penelitian Percobaan, Jilid 1. Bandung : Tarsito

10. Haryanto, B. Dan Pangloli, P. 2009. Potensi dan Pemanfaatan Sagu. Kanisius. Yogyakarta.

11. Hood, L.M. 1980. Carbohydrates and Health. AVI Publishing Company Inc. Westport. Connecticut

12. Hui, Y. H., 1996. Bailey's Industrial Oil and Fat Products Vol 4. Edible Oil and Fat Products : Processing Technology. John Wiley \& Sons, New York

13. Mahmud, M. 2009. Tabel Kompisisi Pangan Indonesia. PT. Gramedia, Jakarta.

14. Matz, S. A. 1972. Bakery Technology and Engineering. Second Edition. The Avi Publishing Co, Inc, Westport, Connecticut.

15. Matz, Samuel. A, dan TD. Matz. 1978. Cookies and Cracker Technology. The Avi Publishing Co, Inc, Westport, Connecticut.

16. Millah, I., 2013. Pembuatan Cookies (Kue Kering) Dengan Kajian Penambahan Apel Manalagi 
(Mallus sylvestris Mill) Subgrade dan Margarin. http//skripsitip.staff.ub.ac.id.id/files/2 014/jurnalirma-ika-izzatumillah.pdf. Diakses 30 Agustus 2016

17. Moorthy, S. N. 2004. Tropical Sources of starch. Didalam : Ann Charlotte Eliason (ed). Starch in Food : Structure, Function, and Application. CRC Press, Baco Raton, Florida

18. Muchtadi, Tien R., dan Ayustaingwarno, Fitriyono. 2010. Teknologi Proses Pengolahan Pangan. Cetakan keempat. Alfabeta. Bandung.

19. Pertiwi, D. 2006. Pengaruh Perbandingan Tepung Kacang Koro dan Tepung Terigu Dengan Pemanggangan Terhadap Karakteristik Biskuit Kacang Koro. Tugas Akhir, Jurusan Teknologi Pangan Fakultas Teknik Universitas Pasundan

20. Setser CS. 1995. Sensory Evaluation. Didalam : Kramel BS dan CE Stauffer (Eds). Advances in Baking Technology. Blakie Academic and Proffesional, Glasgow

21. Smith, W.H. 1972. Biscuit, Crackers and Cookies. Technology. Production and Management. Applied Science Publisher, London.

22. Soekarto, T.S. 1985. Penilaian Organoleptik. Bhratara Karya Aksara, Jakarta.

23. Soliha, I. 2008. Aplikasi Penggunaan Tepung Daging Sapi Sebagai Bahan Substitusi Sebagian Tepung Terigu dalam Pembuatan Cookies. Skripsi. Program Studi Teknologi Hasil Ternak, Fakultas Peternakan, IPB Bogor. Bogor.

24. Standar Nasional Indonesia. 1992. Biskuit. No. 012973-1992. Jakarta.

25. Subagio. A., Witono. Y., dan Wiwik SW. 2002. Protein dan Globullin dari Beberapa Jenis KoroKoroan. Prosiding Seminar Nasional PATPI Kelompok Gizi dan Keamanan Pangan.

26. Sudiyono. 2010. Penggunaan Na2HCO3 untuk Mengurangi Kandungan Asam Sianida (HCN) Koro Benguk pada Pembuatam Koro Benguk Goreng..Agrika. Vol.4(1): 48-53

27. Sumarmono, Juni. 2012. Pengukuran Keempukan Daging Dengan Penetrometer. Laboratorium Teknologi Hasil Ternak, Fakultas Peternakan UNSOED Purwokerto (revisi Mei 2012).

28. Tri Radiyati dan Agusto, W.M.1990 Tepung tapioka (perbaikan). Subang : BPTTG Puslitbang Fisika Terapan - LIPI, 1990 Hal. 10-13.

29. Wardiyono, 2008. Detail Data Cassia fistula.<URL:http://www.kehati.com > diakses pada 12 April 2016.

30. Winarno, F.G., Fardiaz, S., dan Fardiaz, D. (1997). Pengantar Teknologi Pangan. Edisi Ke-3. Penerbit Gramedia. Jakarta.

31. Windrati, W. S. Dkk. 2010 "Sifat Nutrisional protein Rich Flour (PRF) Koro Pedang (Canavalia ensiformis L)”. Jurnal Agrotek: Vol. 4 No.1. 